ppi $201502 Z U 4645$

Esta publicación científica en formato digital es continuidad de la revista impresa ISSN-Versión Impresa 0798-1406 / ISSN-Versión on line 2542-3185Depósito legal pp $197402 Z$ U34

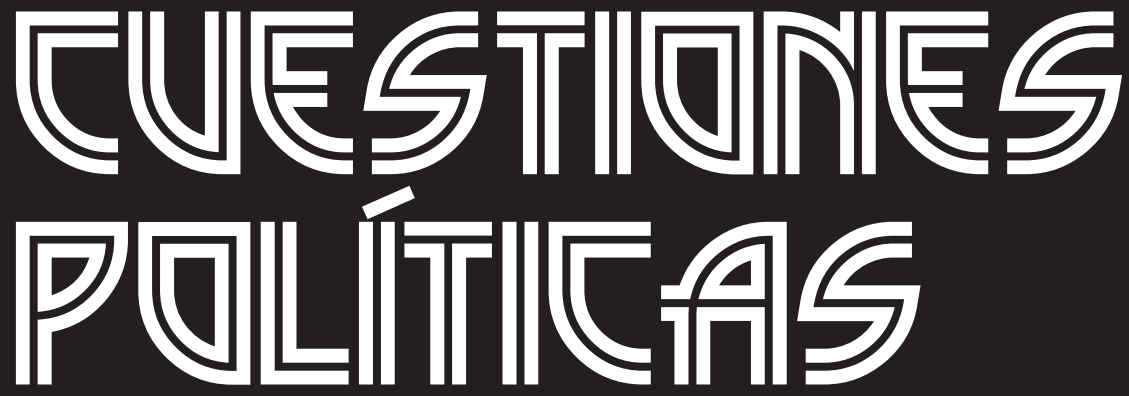

Instituto de Estudios Políticos y Derecho Público "Dr. Humberto J. La Roche" de la Facultad de Ciencias Jurídicas y Políticas de la Universidad del Zulia Maracaibo, Venezuela
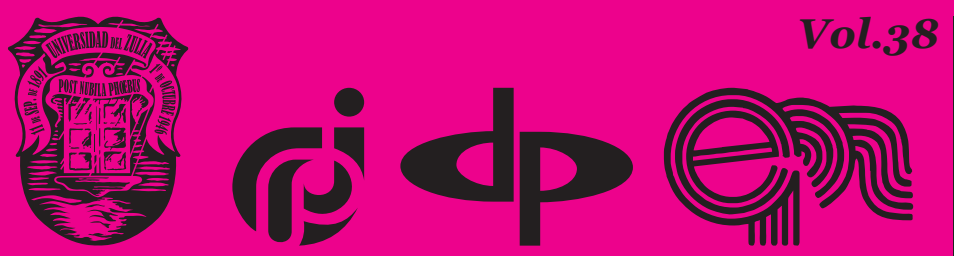

$N^{\circ}$ Especial 1era Parte 2020 


\title{
Approaches to the formation of Public Administration in the Context of Decentralization Reform in Ukraine
}

\author{
DOI: https://doi.org/10.46398/cuestpol.38e.19
}

\author{
Nataliia $V$. Vasylieva * \\ Oleksandra I. Vasylieva ** \\ Sergii M. Prylipko *** \\ Svitlana $V$. Kapitanets $* * *$ \\ Olena V. Fatkhutdinova ${ }^{* * * * *}$
}

\begin{abstract}
Based on the analysis of the works of national and international scientists and professionals availablein the bibliography, the article aimed to reveal a conceptual vision of the application of innovative approaches to the training of public servants in a decentralized environment. Emphasis is placed on solving the urgent problem of public administration that is expressed in the professional capacity of those who form and implement public policies to solve socially significant problems under indeterminate conditions during the implementation of the decentralization reform in Ukraine. Methodologically, the text document analysis technique was used. The authors propose a professional training program for public servants, including community leaders, which is a synthesis of methodological techniques, as well as modern personnel technologies, such as: change management, design thinking, gender approach, human resource management, HR management, time management, etc. By way of conclusion, the convenience of using innovative
\end{abstract}

* Full Doctor in Public Administration, Professor at the Department of Regional Administration, Local Self-Government and Urban Management, National Academy for Public Administration under the President of Ukraine, Ukraine. ORCID ID: https://orcid.org/oooo-0002-3128-7767. E-mail: vasilyeva10@ust-hk.com.cn

** Full Doctor in Public Administration, Professor at the Department of Public Administration and Public Service, National Academy for Public Administration under the President of Ukraine, Ukraine. ORCID ID: https://orcid.org/oooo-0003-1812-4557. Email: vasilyeva01@ust-hk.com.cn

*** Full Doctor in Public Administration, Professor at the Department of Public Administration and Innovation Management, National University of Life and Environmental Sciences of Ukraine, Ukraine. ORCID ID: https://orcid.org/oooo-0o02-5586-0003. Email: prylipko25@tanu.pro

**** Ph.D. in Pedagogy, Associate Professor at the Department of Improvement of Counteraction to Customs Offenses, Research Center of Customs Affair of Research Institute of Fiscal Policy, University of State Fiscal Service of Ukraine, Ukraine. ORCID ID: https://orcid.org/oooo-00o3-0693-5889. Email: sv.kapitan@nuos.pro

*****Full Doctor in Philosophy, Professor at the Department of Law Enforcement and Anti-Corruption, Kyiv University of Tourism, Economics and Law, Ukraine. ORCID ID: https://orcid.org/oooo-00027906-2583. Email: olena1975@tanu.pro 
Nataliia V. Vasylieva, Oleksandra I. Vasylieva, Sergii M. Prylipko, Svitlana V. Kapitanets y Olena V. Fatkhutdinova

Approaches to the formation of Public Administration in the Context of Decentralization Reform in Ukraine

approaches that meet the needs of each consumer of public services and can ensure effective and competitive development of the territories is verified. Furthermore, the article reveals the conceptual provisions that should form the basis of a new model of public service.

Keywords: public servants in Ukraine; administrative decisions; innovation in public services; decentralization in Ukraine; political and administrative reforms.

\section{Enfoques para la formación de la Administración Pública en el Contexto de la Reforma de Descentralización en Ucrania}

\section{Resumen}

Basado en el análisis de los trabajos de científicos y profesionales nacionales e internacionales disponible en la bibliografía, el artículo tuvo por objetivo revelar una visión conceptual de la aplicación de enfoques innovadores a la formación de servidores públicos en un entorno descentralizado. Se enfatiza en la solución del problema urgente de la administración pública que se expresa en la capacidad profesional de quienes forman e implementan políticas públicas para resolver problemas socialmente significativos en condiciones indeterminadas durante la implementación de la reforma de descentralización en Ucrania. Metodológicamente se utilizó la técnica de análisis de documentos de texto. Los autores proponen un programa de formación profesional para servidores públicos, incluidos líderes comunitarios, que es una síntesis de técnicas metodológicas, así como tecnologías modernas de personal, tales como: gestión del cambio, pensamiento de diseño, enfoque de género, gestión de recursos humanos, gestión de RRHH, gestión del tiempo, etc. A modo de conclusión se comprueba la conveniencia de utilizar enfoques innovadores que satisfagan las necesidades de cada consumidor de servicios públicos y se pueda asegurar un desarrollo eficaz y competitivo de los territorios. Además, el artículo revela las disposiciones conceptuales que deberían formar la base de un nuevo modelo de servicio público.

Palabras clave: servidores públicos en Ucrania; decisiones administrativas; innovación en servicios públicos; descentralización en Ucrania; reformas políticas y administrativas. 


\section{Introduction}

The transformation of public administration is manifested in the transformations that allow optimizing the power structure, balancing the relationship between the center and the territories for the efficient use of existing resources (human, financial, natural, property and others) (Vasylieva, 2009). In Ukraine, on the one hand, there is a reform of decentralization of power, and on the other - there is an institutional crisis. Any crisis is a test of the system (state, society, individual) for the ability to function and adequately, systematically and rationally respond to unexpected changes in the current situation. Ineffective mechanisms of interaction between government and society lead to conflicts in the country (Vasylieva and Vasylieva, 2018). The results of the reforms directly depend on the professionalism and responsibility of the management staff that shape and implement public policy, as far as their decisions are clear and meet the needs of the population (Allalyev, 2019; Kerimov et al., 2015).

The realities of life have shown that top business managers, who are committed to formulating public policy aimed at the development of a particular industry, do not understand the peculiarities of public administration, namely - responsible service to all citizens of Ukraine. Referring to the decentralization processes in society, the state tries to abdicate responsibility for organizing proper legal, financial, informational, and other coordination of activities of all participants in crisis management in various spheres and regions of the country. Personnel experiments create conditions in which it is difficult to meet the demands of the population, primarily related to ensuring their safety.

In our opinion, the application of design thinking will allow in complex and uncertain situations to make informed management decisions that will be aimed at meeting the needs of each consumer of public services and ensure effective and competitive development of territories (settlement, region, state). And also, to create added value of the received product qualitative results of realization of reform of decentralization through effective adjustment of activity of public servants and functioning of sphere of public services (Gordadze et al., 2018, Kerimov et al., 2018a; Kerimov et al., 2018b).

The article reviews international and domestic research on selected issues. Scientific publications (Spina, 2013; Muriu, 2013; Moisiu, 2014; Mookherjee, 2014; Sow and Razafimahefa, 2015; Martinez-Vazquez et al., 2017; Troncoso et al., 2017; Bojanic, 2018) allow to identify the causal links that occur between the subjects of decentralization reform. Review of individual reforms in different continents confirmed the dependence of the public service sector on the establishment of relations between 
Nataliia V. Vasylieva, Oleksandra I. Vasylieva, Sergii M. Prylipko, Svitlana V. Kapitanets y Olena V. Fatkhutdinova

Approaches to the formation of Public Administration in the Context of Decentralization Reform 304 in Ukraine

public authorities, citizens and business representatives (education: USA - Edwards and DeMatthews (2014); medicine: Western Europe - Saltman et al. (2007); Rechel et al. (2018); Liwanag and Wyss (2018); agriculture: Understand, analyse and manage a decentralization process (2006).

The authors (Bach, 2001; Burke et al., 2013; Yahiaoui et al., 2015; Daly, 2015; Knies and Leisink, 2018) emphasized the importance of human resource management in the public sector and the involvement of professionally trained officials in public affairs. Staff selection, management and motivation are important for the success of public administration. Any crisis creates space for new social, economic, political and other changes in the development of society, including and to personnel management, public services, etc. (Weber, 1980). It is argued that global and national recessions, crises, conflicts, and catastrophes are a test of the ability of public managers to respond effectively to them (Kellis and Bing, 2013). From this point of view, it is interesting to introduce design thinking as an innovative concept that allows you to analyze, synthesize and find the optimal solution to overcome barriers (Razzouk and Shute, 2012; Lyasnikov and Usmanov, 2019; Kerimov et al., 2018c).

At the same time, the issue of combining bureaucracy based on strict adherence to the rule of law and procedures and the application of innovative approaches to management decisions remains unsolved. The key problem is the professional ability of those who shape and implement public policy to solve socially significant problems in an indeterminate environment during the implementation of decentralization reform. This requires the application of innovative approaches to the training of public servants, which led to the feasibility of researching the subject of the article. Analyze the work of international and domestic scholars and practitioners on the formulation of an innovative conceptual vision for training in public administration in the implementation of the reform of decentralization of power. Justify the need to apply innovative approaches, including design thinking, to the training program for civil servants.

\section{Materials and Methods}

To form the source base, the method of analysis of full-text documents by keywords was used: decentralization reform, public service, management decisions, innovations, design thinking, services. The search was not limited to geography, language, time of publication of scientific publications and research format, which allowed a comprehensive study of the subject of the selected issue. In the conditions of transformation processes taking place in public administration in Ukraine, it is necessary to apply the synthesis of methodological techniques, as well as modern personnel technologies, 
in particular such as: change management, human resources management, HR-management, time management, design thinking and others.

Change management involves the simultaneous implementation of management functions and integrated application of different approaches (interdisciplinary, systemic, situational, program-target, project, genderoriented, synergetic, behavioral, competence and others) to management decisions. The process of managerial decision-making in the field of public administration requires from those who develop, adopt and implement a high level of competence, responsibility, significant time, energy and experience, i.e. the establishment of effective and coordinated work of the entire public authority.

Human resource management and HR-management relate to the provision and effective use of personnel, their professional and social development. The application of time management allows to plan tasks properly, set priorities and functionally apply their skills in assessing personal and managerial effectiveness and efficiency, analyzing the goals achieved in strategic and operational planning, program, and project development. World trends in human resource management are global in nature and reflect the processes of finding different structures in the public and private environment and the creation of highly effective systems for the realization of creative and productive potential. The Japanese philosophy of management (kaizen) is interesting for application in the field of public administration in Ukraine.

According to it, the attention of the company's management (in our case - the public authority) focuses on the continuous improvement of its team, departments, and the organization as a whole, mainly due to existing internal reserves. The mandatory involvement of all employees in the processes taking place in the organization contributes to the fact that qualitative changes occur immediately and at all levels (in each place) in a form understandable to employees, and not imposed from above. The responsibility for change lies with the entire organization, not just top managers. Because each employee has the opportunity to freely consider and choose any interesting and useful initiative that helps to improve the effectiveness of its activities, reduce time, energy, etc., and will have a positive response from those to whom its activities are directed (consumers of services). This allows to obtain a significant synergetic effect from the adoption and implementation of management decisions in the context of decentralization reform.

Mastering the approach of design thinking and its further use in management involves the concept of human-centeredness, adherence to the principles of gender equality and social justice (focusing on the interests and needs of people, regardless of gender, age, position, social and financial status, etc.); multidisciplinarity (combination of knowledge from 
Nataliia V. Vasylieva, Oleksandra I. Vasylieva, Sergii M. Prylipko, Svitlana V. Kapitanets y Olena V. Fatkhutdinova

Approaches to the formation of Public Administration in the Context of Decentralization Reform

different spheres of human life to overcome problems in indeterminate conditions); integrity, cooperation (comprehensive analysis and common understanding of crisis phenomena, joint development of management decisions), etc. Design thinking involves understanding the object of study, analyzing problematic aspects, visualizing innovative ideas, evaluating them for realism and further implementation.

Gender mainstreaming is a qualitative measurement of the processes of planning, implementation, monitoring, evaluation and control of programs and projects in political, socio-economic, environmental and other spheres of life to create favorable conditions for women and men to have equal opportunities to benefit and benefit from implementation of adopted programs and projects. Gender analysis is integrated into all stages of strategic, program-target planning, programming and design and improves the quality of decisions and the effectiveness of planned activities.

\section{Results and Discussion}

In the XXI century intensive changes in the field of human resources (in global, national, regional, sectoral, demographic, corporate, professional, and individual dimensions) are becoming revolutionary. In the field of HRmanagement there are radical changes from the former professional role stereotypes of the administrator-bureaucrat and the head to essentially new roles: the leader, the strategist, the businessman, the tutor (coach). This is manifested in the implementation of reforms in various spheres of life. Human resources are a key factor in the development of society. The speed and quality of implementation of the declared sectoral and sectoral changes, the competitiveness of the national economy and the standard of living of the population depend on the professional qualifications of public servants, their compliance with European standards of public service. There is an urgent need in the state to change the management paradigm of formation and implementation of personnel policy, development of a model of an effective personnel system, introduction of new technologies (Guliyev et al., 2018; Guliyev et al., 2017).

The intensity of interaction and the growth of the diversity of social relations affect people's communication, satisfying their need for communication. Dialogue is the highest form of communication, which is characterized by such features as: the presence of purpose; focus on finding the truth, which should be the same for all participants; subjectsubject character; equality of participants, tolerance and responsibility; achieving mutual understanding and rational interaction in the field of communicative and practical activities; measurability of the result (Petroe, 2012). In the process of communication, a sociable community is formed, 
which is characterized by relations of unity, interconnectedness, and mutual understanding (Osovska, 2003).

Nowadays, to make management decisions in the field of public administration is not enough to have the necessary knowledge in the economic, legal and socio-humanitarian spheres, the main thing is to be able to effectively apply skills and abilities in practice. In modern conditions, the training system should meet the needs of public authorities and other bodies and organizations in employees with a high level of professionalism and culture, able to competently and responsibly perform management functions, implement the latest social technologies, promote innovation. This allows us to identify ways to improve the system of training and retraining of public servants.

The content and level of their professional training should correspond to the strategic directions of statehood development, be of an advanced nature, consider the high dynamism of social and economic processes, the key tasks of public administration reform. High quality of their training is achieved through the use at all levels of vocational education, developed educational and scientific base, integrated multilevel curricula, attracting highly qualified teaching staff to conduct the educational process in vocational education programs (Prylipko, 2019). Therefore, in Ukraine at the present stage it is necessary:

- to modernize the system of continuous professional training of civil servants and local government officials with the use of e-government technologies, involvement of leading domestic and foreign specialists in the field of public administration and administration, providing professional internships abroad, etc.

- to update educational standards of vocational training with an emphasis on the ability to respond in a timely manner to changes caused by decentralization reform.

- to increase the financial support of the system of training and advanced training in accordance with European standards, which will improve the material and technical base and the quality of the organization of the educational process.

- to improve the methodology for assessing the effectiveness of improving the professional competence of civil servants and local government officials.

- to update approaches to the formation of the personnel reserve in the public service.

Local government officials should be initiators and designers of democratic transformations, effective managers, team leaders in their communities (Vasylieva et al., 2017). Leaders play a leading role in staffing 
Nataliia V. Vasylieva, Oleksandra I. Vasylieva, Sergii M. Prylipko, Svitlana V. Kapitanets y Olena V. Fatkhutdinova

308

Approaches to the formation of Public Administration in the Context of Decentralization Reform in Ukraine

public administration. Leadership implementation is of paramount importance and importance for improving effective and efficient interpersonal subject-object relationships. Leadership provides a search for the most rational forms and methods of management, the application of which depends not only on the effectiveness of each element of the local government system and each employee, but also the effectiveness of decentralization reform as a whole. The new role of management is not to stand at the top of the pyramid and control subordinates, but to give them new strength and opportunities (Grishchenko, 2016). This model of relations consists of its innovative methods, staffing, tools and more. Through the use of influencing technologies, it is possible to effectively unite people around the solution of certain issues (Kerimov et al., 2017; Kerimov et al., 2019).

In our opinion, such an innovative approach as design thinking should be used in the training of personnel in the field of public administration (especially leaders of territorial communities). This approach allows to develop such skills of public servants as initiative, creativity, originality and critical thinking, analysis, generation of ideas (Gusakov, 2019). The use of various methods and technologies in complex, non-standard and uncertain situations will allow managers to comprehensively solve existing problems (Kerimov et al., 2016; Kerimov and Rachinsky, 2016).

For the first time, "design thinking" was used in business by IDEO, on the initiative of which a design school was established at Stanford University. This approach aims to develop innovations in indeterminate conditions and in high competition (Gejderih, 2018). It was IDEO President Brown (2008) who justified the new concept in response to the growing need of business for innovative solutions to meet the challenges of the global market. According to T. Brown (2008), the first to use "design thinking" was T. Edison, who in his work focused on human needs. Innovation is the result of observing and understanding exactly what people want, what they like or dislike, what and how to manufacture, package, sell and continue to support a particular product (Kuznetsov et al., 2018).

Nowadays, the problem of development of design thinking is relevant for various spheres of human activity (Lyasnikov and Usmanov, 2019; Almomani and Bystrova, 2019). The design thinking model consists of $4 \mathrm{P}$ : people, process, place and partnerships and allows you to qualitatively develop and implement innovative ideas (Müller-Roterberg, 2018). Design thinking begins with people, not with technology or business goals, so it can be used in the development and implementation of various social initiatives (Brown and Wyatt, 2010; Lapidus et al., 2018a).

We believe that design thinking allows you to meticulously, objectively, optimistically, constructively analyze the "product" that is being studied to meet the needs of people who will consume a product or service, or use 
a specific infrastructure. For example, how to make a local community attractive to its residents so that they do not have the idea to leave it (move to another area)? Or how to make an educational, medical, or other institution so that it is in demand and competitive in the services market? We are not talking about paid services, but about the positive consequences for human resource development.

The same applies to political decisions on a national and local scale. How to ensure the implementation of the reform of decentralization and territorial organization of power (financial, personnel, information, and other resource aspects)? That is, this concept combines emotional, functional and process (technological) components. There are various scientific approaches (Hobcraft, 2017; Müller-Roterberg, 2018) to understanding the content of the stages of design thinking: Empathize/Understand - Define/ Observe - Ideate/Visualize - Prototype/Evaluate - Test/Implement. Consider these stages on the example of the activities of local government officials, which is to make management decisions regarding the provision of public services (Lapidus et al., 2018b; Lapidus et al., 2018c).

People react differently to events in their lives, that is why they subjectively assess the situations in which they find themselves. It is design thinking that aims to correct the emotions that are part of any process. Thus, at the stage of "Empathize/Understand" there is an understanding of the person who applied to the public authority: his needs, behavior, emotions, which allows you to build the right communications, especially the feedback between the provider and the end user of the service. The key tools are interviews, surveys, questionnaires, sociological, marketing, and other research, which allows you to gather the necessary information. This is an important stage in the formation and implementation of public policy in a particular area at the national, regional and local levels (Pogosyan et al., 2018).

Sometimes civil servants make decisions in the absence of empirical data, for example, on the establishment of public transport, the creation of public space and more. We believe that the use of gender mainstreaming is useful at the "Define/Observe" stage. The decentralization reform stipulates the revision of legal documents for the provision of public services (Order of the Ministry of Finance of Ukraine, 2019). In many European countries, scholars focus on the issue of achieving gender equality in the formation and implementation of public policy (adoption of strategic and operational documents, implementation of appropriate measures), etc. (Daly, 2005; Gender Equality in Public Services, 2007; Bettio and Sansonetti, 2015; Sansonetti et al., 2018; Pogosyan et al., 2019).

In our opinion, knowledge, and skills in applying a gender approach to the management decision-making process are very necessary in the process of training qualified personnel in the field of public administration. 
Nataliia V. Vasylieva, Oleksandra I. Vasylieva, Sergii M. Prylipko, Svitlana V. Kapitanets y Olena V. Fatkhutdinova

Approaches to the formation of Public Administration in the Context of Decentralization Reform

Questionnaires provide complete information on the real situation of gender equality. Thus, for example, the question can be answered: will the analyzed object be convenient, accessible and comfortable for all residents and guests of the city: people of different sexes, ages, with small children, with disabilities, with animals or bicycles, for foreigners? Gender auditing can address staffing issues and address inclusive access to public services. It is desirable to use gender impact assessment when formulating targeted budget programs. Thus, it allows to obtain positive results in the planning and implementation of public authorities in various areas of their activities.

At the "Ideate/Visualize" stage, the created working groups discuss ideas, select alternative proposals in terms of their clarity and how to implement them in a certain period of time. The differences between future (projected) benefits and resource costs (financial, time, human and other) during the implementation of a particular project are clarified. In our opinion, due to ignoring the "Prototype/Evaluate" stage in practice, there are often cases of reworking the work performed and increasing the amount of resources spent. For example, the creation of inclusive infrastructure, public spaces and more. The result of the previous stages is "Test/Implement", the key point of which is to receive feedback from end users of services and take into account the relevant comments - suggestions when adjusting if necessary. Thus, design thinking is a heuristic method of studying existing problems in conditions of uncertainty.

On the example of the author's(Prylipkoetal.,2019) professional program "Management of sustainable development of the territorial community" we propose to consider the application of innovative approaches to the training of public servants in a decentralized environment. The program consists of 5 credits ( 5 topics), which are a set of practice-oriented trainings (Table 1 ).

\section{Table 1. The structure of the professional training program "Management of sustainable development of the territorial community"}

\begin{tabular}{|c|l|}
\hline No & \multicolumn{1}{|c|}{ The title of the topic of the content module } \\
\hline 1 & $\begin{array}{l}\text { Ensuring economic, social, and environmental security of the } \\
\text { territorial community in indeterminate conditions. }\end{array}$ \\
\hline 2 & $\begin{array}{l}\text { Application of a gender-oriented approach to management } \\
\text { decision-making in the activities of the management team. }\end{array}$ \\
\hline 3 & $\begin{array}{l}\text { Design thinking and creation of a creative and competitive } \\
\text { territorial community on the basis of sustainable development. }\end{array}$ \\
\hline 4 & $\begin{array}{l}\text { Synergetic approach to the development of public services in the } \\
\text { local community. }\end{array}$ \\
\hline 5 & $\begin{array}{l}\text { Development of urban areas on the basis of sustainable } \\
\text { development. }\end{array}$ \\
\hline
\end{tabular}


Topic 1. Sustainable development as a priority of the Local Leader Program. It is planned to analyze the goals of sustainable development, determine the criteria and indicators for achieving the comfort of living in the local community. Get answers to the questions:

- How to effectively manage existing and how to find new resources of the local community (human, natural, land, financial, information, logistics and others)?

- How to correctly implement such a priority of municipal policy as the implementation of economic (business) activities in the territorial community, especially in terms of unification?

- How to establish inter-municipal cooperation?

- How to create innovative formations (clusters, industrial, technology parks, etc.) and with their help to achieve "sustainable" community growth?

Topic 2. The activities of the management team involve making management decisions to ensure sustainable development of the local community, and this requires understanding the algorithm and tools for developing, making, and implementing management decisions and effective communication in the community. It is important to understand the essence and purpose of gender tools, to be able to conduct different types of gender analysis. Be able to apply in practice a gender-oriented approach to the development of small and medium-sized businesses, employment, forecasting and planning of strategic, targeted and budget programs. It is also important to evaluate and monitor the effectiveness and efficiency of strategic, targeted and budget programs and projects to ensure sustainable development of the local community (achieving the goals of sustainable development, gender equality and social justice with respect to the principle of inclusion).

Topic 3. Application of innovative approaches to management decisions on public management and administration of sustainable development of the local community, which involves understanding how to use technology in practice: design thinking, benchmarking, municipal marketing, HRmanagement and more. As well as manage change, use a participatory approach (involving residents in the development of the local community, the use of forms of direct democracy); project approach (project management, public-private partnership, concession, etc.); smart technology (creating a "smart" local community) and others in carrying out their professional activities, which will attract investment in the development of the territorial community. The community leader must know how to create conditions for the emergence and development of cultural and creative industries, areas (for instance, tourism) using digital technologies. How to achieve profitability of the local budget in the conditions of globalization, to increase 
Nataliia V. Vasylieva, Oleksandra I. Vasylieva, Sergï M. Prylipko, Svitlana V. Kapitanets y Olena V. Fatkhutdinova

Approaches to the formation of Public Administration in the Context of Decentralization Reform

the level of employment and public involvement in the processes taking place in the settlement, to expand access to new international opportunities, markets, and audiences.

Topic 4. It is important to understand the achievement of synergies and compliance with quality standards, and to do this to know the methods of achieving a high level of quality. This will allow to develop the social and humanitarian sphere in such a way that there are provided quality and accessible public services to residents; municipal infrastructure (housing and communal, transport, communications, etc.), to create centers of municipal services, to implement digital technologies.

- How can sociological research be used to assess the level of public satisfaction with the services provided?

- How to conduct a gender audit of accessibility and take into account the principle of inclusion?

- How to model the best options for making customer-oriented management decisions?

Topic 5. How to develop the territorial community in the conditions of urbanization and creation of agglomerations? It is important for the leaders of territorial communities to address issues of urban planning in the face of today's challenges: master plans, zoning, problems of urban architecture, landscaping, creation of public spaces and more. Territorial community for people: modernization of industrial, historical, natural zones. Revitalization as a tool for the revival of abandoned territory: algorithm, examples of project implementation (domestic and foreign experience).

A public servant (especially a manager) should have an appropriate set of competencies and professional qualities, and his position should meet the qualification requirements. In the process of decentralization reform, professionals must have a thorough knowledge of the legal framework, have analytical thinking, based on systematic analysis to make economically sound and socially responsible management decisions in terms of change and innovation, participate in the development of strategic documents, project management, to establish communication links on the basis of modern information technologies, to show leadership skills, to organize work and to control its implementation, to establish social cooperation between stakeholders, etc., (Prylipko et al., 2019).

The proposed program is primarily designed to train leaders of local communities. Students at the end of the training will obtaine the following skills:

- effectively organize the work of yourself and your team and properly manage time. 
- apply innovative approaches to the formation of municipal policy for sustainable development of the territorial community in indeterminate conditions.

- to analyze the available potential of the city and to determine priority directions during development of strategic and target programs of development and carrying out of budgetary policy.

- to organize collective events in the field of urban planning in order to increase the comfortable living of residents.

- develop and make service-oriented decisions to improve the functioning of institutions and organizations that provide a variety of services to residents.

- use a system of techniques, methods, and methods for making and implementing socially responsible management decisions focused on the needs and interests of women and men of different ages and social groups in compliance with the principle of inclusion.

- to establish effective communication with the community (public inquiries, involvement of residents in management decisions through the use of various forms of direct democracy) and achieve results to ensure sustainable development of the territorial community, comfortable with a high quality of life for all segments of the population;

- to organize a quality process for project development with the involvement of the community, to show initiative and entrepreneurship.

- to apply methods of strategic management of the population, the deputy corps, the executive body of local self-government, the community, mass media, as bases of maintenance of achievement of the purposes of sustainable development of territorial community.

\section{Conclusion}

Analysis of the researches of international and domestic scholars and practitioners allowed us to formulate our own conceptual vision for the integrated application of innovative approaches to staff training in the sphere of public administration, which allows to obtain quality results in the implementation of decentralization reform in Ukraine. Thus, the new model of virtuous public service in Ukraine should be based on the following conceptual provisions: 
Nataliia V. Vasylieva, Oleksandra I. Vasylieva, Sergii M. Prylipko, Svitlana V. Kapitanets y Olena V. Fatkhutdinova

Approaches to the formation of Public Administration in the Context of Decentralization Reform in Ukraine

- Public service is built around the strategic needs and interests of people, local communities, and society as a whole.

- Formation of the system and determination of the number of public service bodies takes into account the integral ability of its subjects to cooperate effectively to achieve concrete social results, which together will improve the quality of life and security of the people on a permanent basis;

- The principles of organization of public service in the state are clear to society and ensure its openness, transparency, and accountability of the people.

- Civil servants are constantly increasing their productivity and reducing the cost of providing public services.

- Conditions of public service attract, retain, and stimulate productive activities of talented and qualified professionals, with respect to gender equality.

- Civil servants interact with the public to obtain concrete common results.

- Public structures are provided with resources that are sufficient to achieve certain goals, including reliable information that is not narrowly focused, but systemic.

- The state has a high level of public confidence in public institutions.

This, in turn, requires the use of a synthesis of methodological techniques, innovative approaches (interdisciplinary, systemic, situational, programtargeted, project, gender-oriented, synergetic, behavioral, competence and others) and technologies (change management, human resource management, HR-management, time management, design thinking and others) to the implementation of personnel of their professional activities. Meeting the interests and needs of the inhabitants of territorial communities requires the application of knowledge from various spheres of human life, a comprehensive understanding and analysis of crisis phenomena, the ability to cooperate with others. This will allow you to make and implement quality management decisions (in the form of appropriate programs and projects) to overcome the identified problems in a particular area.

The indeterminate conditions in which Ukraine finds itself recently make managers need to carefully study foreign experience and adapt its best practices, such as kaizen, design thinking, meritocracy, gender and others, to their professional activities in the field of public administration. To conclude, the model of virtuous public service today requires the use of innovative approaches in the training of civil servants in a decentralized environment, which is really important for overcoming the problems of corruption, secrecy and public trust. 


\section{Bibliographic References}

ALLALYEV, Ruslan. 2019. "Religious origins of the rule of law conception in the United States” In: Amazonia Investiga. Vol. 7, No. 14, pp. 212-217.

ALMOMANI, Khaled; BYSTROVA, Tatyana. 2019. "Design thinking algorithms: theory and practice” In: Academic Bulletin Uralniproekt RAASN. No. 2, pp. 92-97.

BACH, Stephen. 2001. HR and new approaches to public sector management: improving HRM capacity. Available online. In: https://www.who.int/ hrh/en/Improving_hrm_capacity.pdf. Consultation date: 18/07/2020.

BETTIO, Francesca; SANSONETTI, Silvia. 2015. Visions for gender equality. Publications Office of the European Union. Luxembourg.

BOJANIC, Antonio. 2018. "The impact of fiscal decentralization on accountability, economic freedom, and political and civil liberties in the Americas" In: Economies. Vol. 6. No. 8, pp. 2-20.

BROWN, T.; WYATT, Jocelyn. 2010. "Design thinking for social innovation” In: Stanford Social Innovation Review. Available online. In: https://ssir.org/ articles/entry/design_thinking_for_social_innovation. Consultation date: $10 / 07 / 2020$.

BROWN, Tim. 2008. "Design thinking” In: Harvard Business Review. No. 6, pp. 1-10. Available online. In: https://readings.design/PDF/Tim\%20 Brown,\%20Design\%20Thinking.pdf. Consultation date: 03/07/2020.

BURKE, Ronald; ALLISEY, Amanda; NOBLET, Andrew. 2013. “The importance of human resource management in the public sector, future challenges and the relevance of the current collection" In: Human Resource Management in the Public Sector. No. 3, pp. 1-13.

DALY, John. 2015. Human resource management in the public sector policies and practices. Routledge. London: England.

DALY, Mary. 2005. "Gender Mainstreaming in theory and practice" In: Social Politics. Vol. 12, No. 3, pp. 433-450.

EDWARDS, Brent; DEMATTHEWS, David. 2014. "Historical trends in educational decentralization in the United States and developing countries: A periodization and comparison in the post-WWII context" In: Education Policy Analysis Archives. Vol. 22, No. 40, pp. 1-39. 
Nataliia V. Vasylieva, Oleksandra I. Vasylieva, Sergii M. Prylipko, Svitlana V. Kapitanets y Olena V. Fatkhutdinova

Approaches to the formation of Public Administration in the Context of Decentralization Reform

GEJDERIH, Pavel. 2018. "Design thinking as a promising way to generate and develop innovations" In: Bulletin of the Tver State University. Economics and Management. No. 3, pp. 245-254.

GENDER EQUALITY IN PUBLIC SERVICES. 2007. Some useful advice on gender mainstreaming. Available online. In: https://www.government. se/legal-documents/2007/04/sou-200715/. Consultation date: 22/07/2020.

GORDADZE, Guram; KERIMOV, Vagif; GIRUTS, Maksym; POSHIBAEVA, Alexandra; KOSHELEV, Vladimir. 2018. "Genesis of the asphaltite of the Ivanovskoe field in the Orenburg region, Russia” In: Fuel. Vol. 216, pp. 835-842.

GRISHCHENKO, Iryna. 2016. The phenomenon of leadership in the system of local self-government: theory, methodology, practice. NAPA. Kyiv, Ukraine.

GULIYEV, Ibrahim; KERIMOV, Vagif; MUSTAEV, Rustam; BONDAREV, Andrey. 2018. "The estimation of the generation potential of the low permeable shale strata of the Maikop Caucasian series" In: Socar Proceedings. No. 1, pp. 4-20.

GULIYEV, Ibrahim; KERIMOV, Vagif; OSIPOV, Alexander; MUSTAEV, Rustam. 2017. "Generation and accumulation of hydrocarbons at great depths under the earth's crust” In: Socar Proceedings. No. 1, pp. 4-16.

GUSAKOV, Alexandr. 2019. "The formation of design thinking skills among managers in the fourth industrial revolution" In: Bulletin of Saratov University. New Series. Series: Economics. Management. Law. Vol. 19, No. 2, pp. 147-154.

HOBCRAFT, Paul. 2017. Improving the potentialfor innovation through design thinking. Available online. In: https://www.hypeinnovation.com/hubfs/ content/reports/design-thinking-improving-potential-innovation.pdf. Consultation date: 14/07/2020.

KELLIS, Dana; BING, Ran. 2013. "Modern leadership principles for public administration: time to move forward" In: Journal of Public Affairs. Vol. 13, No. 1, pp. 130-141.

KERIMOV, Vagif; GORBUNOV, Aleksey; LAVRENOVA, Elena; OSIPOV, Alexander. 2015. "Models of hydrocarbon systems in the Russian Platform-Ural junction zone" In: Lithology and Mineral Resources. Vol. 50, No. 5, pp. 394-406. 
KERIMOV, Vagif; GORDADZE, Guram; LAPIDUS, Albert; GIRUTS, Maksym; MUSTAEV, Rustam; MOVSUMZADE, Eldar; ZHAGFAROV, Fyrdaves; ZAKHARCHENKO, Maryia. 2018a. "Physicochemical properties and genesis of the asphaltites of Orenburg oblast" In: Solid Fuel Chemistry. Vol. 52, No. 2, pp. 128-137.

KERIMOV, Vagif; LAPIDUS, Albert; YANDARBIEV, Nurdyn; MOVSUMZADE, Eldar; MUSTAEV, Rustam. 2017. "Physicochemical properties of shale strata in the Maikop series of Ciscaucasia" In: Solid Fuel Chemistry. Vol. 51, No. 2, pp. 122-130.

KERIMOV, Vagif; LEONOV, Mikhail; OSIPOV, Alexander; MUSTAEV, Rustam; HAI, Vu. 2019. "Hydrocarbons in the basement of the South China Sea (Vietnam) shelf and structural-tectonic model of their formation" In: Geotektonika. Vol. 53, No. 1, pp. 42-59.

KERIMOV,Vagif; MUSTAEV, Rustam; BONDAREV,Andrey. 2016. "Evaluation of the organic carbon content in the low-permeability shale formations (as in the case of the Khadum suite in the Ciscaucasia region)" In: Oriental Journal of Chemistry. Vol. 32, No. 6, pp. 3235-3241.

KERIMOV, Vagif; MUSTAEV, Rustam; OSIPOV, Alexander. 2018b. "Peculiarities of hydrocarbon generation at great depths in the crust" In: Doklady Earth Sciences. Vol. 483, No. 1, pp. 1413-1417.

KERIMOV, Vagif; RACHINSKY, Michael. 2016. "Geofluid dynamic concept of hydrocarbon accumulation in natural reservoirs" In: Doklady Earth Sciences. Vol. 471, No. 1, pp. 1123-1125.

KERIMOV, Vagif; RACHINSKY, Mykhayl; MUSTAEV, Rustam; SERIKOVA, Uliana. 2018c. "Geothermal conditions of hydrocarbon formation in the South Caspian basin” In: Iranian Journal of Earth Sciences. Vol. 10, No. 1, pp. 78-89.

KNIES, Eva; LEISINK, Peter. 2018. "People management in the public sector" In: HRM in Mission Driven Organizations, No. 10, pp. 15-46.

KUZNETSOV, Nykolai; KERIMOV, Vagif; OSIPOV, Alexander; BONDAREV, Andrey; MONAKOVA, Aleksandra. 2018. "Geodynamics of the Ural foredeep and geomechanical modeling of the origin of hydrocarbon accumulations" In: Geotectonics. Vol. 52, No. 3, pp. 297-311.

LAPIDUS, Albert; KERIMOV, Vagif; MUSTAEV, Rustam; MOVSUMZADE, Eldar; ZAKHARCHENKO, Maryia. 2018a. "Caucasus Maykopian Kerogenous shale sequences: generative potential” In: Oil Shale. Vol. 35, No. 2, pp. 113-127. 
Nataliia V. Vasylieva, Oleksandra I. Vasylieva, Sergii M. Prylipko, Svitlana V. Kapitanets y Olena V. Fatkhutdinova

Approaches to the formation of Public Administration in the Context of Decentralization Reform in Ukraine

LAPIDUS, Albert; KERIMOV, Vagif; MUSTAEV, Rustam; MOVSUMZADE, Eldar; SALIKHOVA, Irina; ZHAGFAROV, Fyrdaves. 2018b. "Natural bitumens: physicochemical properties and production technologies" In: Solid Fuel Chemistry. Vol. 52, No. 6, pp. 344-355.

LAPIDUS, Albert; KERIMOV, Vagif; TRET'YAKOV, Valentyn; TALYSHINSKII, Rashyd; ILOLOV, Akhmadsho; MOVSUMZADE, Eldar. 2018c. "Extraction of Asphaltite with Toluene" In: Solid Fuel Chemistry. Vol. 52, No. 4, pp. 256-259.

LIWANAG, Harvy; WYSS, Kaspar. 2018. "What conditions enable decentralization to improve the health system? Qualitative analysis of perspectives on decision space after 25 years of devolution in the Philippines” In: PLoS ONE. Vol. 13, Article Number e0206809.

LYASNIKOV, Nikolaj; USMANOV, Daler. 2019. "Design thinking” of artificial intelligence to overcome barriers" In: Market Economy Problems. No. 3, pp. 45-53.

MARTINEZ-VAZQUEZ, Jorge; LAGO-PEÑAS, Santiago; SACCHI, Agnese. 2017. "The impact of fiscal decentralization: A survey" In: Journal of Economic Surveys. Vol. 31, No. 4, pp. 1095-1129.

MOISIU, Alexander. 2014. "Decentralization and the Increased autonomy in Local Governments" In: Procedia - Social and Behavioral Sciences. No. 109, pp. 459-463.

MOOKHERJEE, Dilip. 2014. "Political Decentralization" In: Annual Review of Economics. No. 7, pp. 231-249.

MÜLLER-ROTERBERG, Christian. 2018. Handbook of design thinking. Tips \& tools for how to design thinking. Available online. In: https:// www.researchgate.net/publication/329310644. Consultation date: 08/07/2020.

MURIU, Abraham. 2013. "Decentralization, citizen participation and local public service delivery: A study on the nature and influence of citizen participation on decentralized service delivery in Kenya" In: Schriftenreihe für Public und Nonprofit Management, 17. Available online. In: http://nbn-resolving.de/urn:nbn:de:kobv:517-opus-65085. Consultation date: 21/07/2020.

ORDER OF THE MINISTRY OF FINANCE OF UKRAINE. 2019. On approval of the Methodological recommendations for the implementation and application of a gender-oriented approach in the budget process. Available online. In: https://zakon.rada.gov.ua/rada/show/vooo120119. Consultation date: 03/07/2020. 
OSOVSKA, Galina. 2003. Communications in management. Kondor. Kyiv, Ukraine.

PETROE, Olga. 2012. "The theory of social partnership and its impact on the development of the concept of social dialogue" In: Bulletin of the National Academy of Public Administration under the President of Ukraine. No. 4, pp. 234-243.

POGOSYAN, Vardhes. 2018. "Philosophies of social behavior research: metaanalytic review” In: Wisdom. Vol. 11, No. 2, pp. 85-92.

POGOSYAN, Vardhes. 2019. "Change and variability of phenomena in complex social systems” In: Wisdom. Vol. 13, No. 2, pp. 95-103.

PRYLIPKO, Serhii. 2019. Development of service cooperation of rural areas: Theory and practice. August Trade LLC. Kyiv, Ukraine.

PRYLIPKO, Serhii; VASYLIEVA, Oleksandra; VASYLIEVA, Nataliia. 2019. "Methodology of forming a comprehensive mechanism for public administration of service cooperation development in rural areas of Ukraine" In: International Journal of Recent Technology and Engineering. Vol. 8, No. 4S, pp. 152-156.

RAZZOUK, Rim; SHUTE, Valerie. 2012. "What is design thinking and why is it important?" In: Review of Educational Research. Vol. 82, No. 3, pp. 330-348.

RECHEL, Bernd; DURAN, Antonio; SALTMAN, Richard. 2018. What is the experience of decentralized hospital governance in Europe? 10 case studies from Western Europe on institutional and accountability arrangements. Available online. In: https://www.euro.who.int/ data/assets/pdf_file/ooo7/377368/policy-brief-28-eng.pdf?ua=1. Consultation date: 28/07/2020.

SALTMAN, Richard; BANKAUSKAITE, Vaida; VRANGBAEK, Karsten. 2007. Decentralization in health. Care strategies and outcomes. Open University Press. New York, United States.

SANSONETTI, Silvia; DE MICHELI, Barbara; PALMEN, Rachel; WROBLEWSKI, Angela. 2018. Gender equality plans in the private and public sectors in the European Union. Available online. In: https:// www.researchgate.net/publication/326547751_Gender_Equality_ Plans_in_the_private_and_public_sectors_in_the_European_Union Consultation date: 13/07/2020.

SOW, Mousse; RAZAFIMAHEFA, Ivohasina. 2015. Fiscal decentralization and the efficiency of public service delivery. Available online. In: https:// 
Nataliia V. Vasylieva, Oleksandra I. Vasylieva, Sergii M. Prylipko, Svitlana V. Kapitanets y Olena V. Fatkhutdinova

Approaches to the formation of Public Administration in the Context of Decentralization Reform

www.imf.org/external/pubs/ft/wp/2015/wp1559.pdf. Consultation date: 19/07/2020.

SPINA, Nicholas. 2013. "Explaining political decentralization in parliamentary democracies" In: Comparative European Politics. Vol. 11, No. 4. Available online. In: https://www.researchgate.net/publication/263325810. Consultation date: $23 / 07 / 2020$.

TRONCOSO, Carmela; ISAAKIDIS, Marios; DANEZIS George; HALPIN Harry. 2017. "Systematizing decentralization and privacy: Lessons from 15 years of research and deployments" In: Proceedings on Privacy Enhancing Technologies. No. 4, pp. 307-329.

UNDERSTAND, ANALYSE AND MANAGE A DECENTRALIZATION PROCESS. 2006. The RED-IFO Model and its use. Available online. In: http://www.fao.org/3/a-a0876e.pdf. Consultation date: 06/07/2020.

VASYLIEVA, Oleksandra. 2009. Regional management in terms of reforming power relations. Yuho-Vostok. Donetsk, Ukraine.

VASYLIEVA, Oleksandra;VASYLIEVA, Nataliia. 2018. “Conflict management in interaction of bodies of public authority and public administration at local level” In: East Journal of Security Studies. Vol. 3, No. 1. Available online. In: http://repositsc.nuczu.edu.ua/bitstream/123456789/8940/1/ Vasiljeva.pdf. Consultation date: 05/07/2020.

VASYLIEVA, Oleksandra; VASYLIEVA, Nataliia; IGNATENKO, Oleksandr. 2017. Staffing of local authorities in the field of public services. NAPA. Kyiv, Ukraine.

WEBER, Max. 1980. Wirtschaft und Gesellschaft. Grundriß der verstehenden Soziologie.Availableonline.In:http://www.zeno.org/nid/2001143905X. Consultation date: 12/07/2020.

YAHIAOUI, Naima; ANSER, Ahlem; LAHOUEL, Samia. 2015. "Human Resource management and public organizations" In: Global Journal of Human Resource Management. Vol. 3, No. 2, pp. 1-12. 


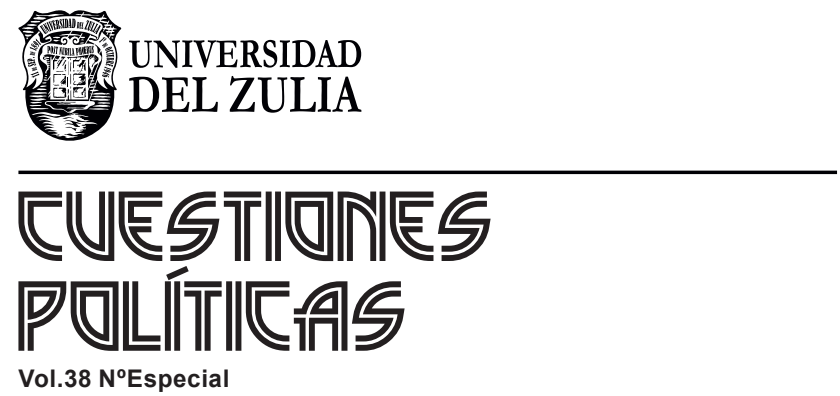

www.luz.edu.ve 